\title{
Clinical Findings before and after the Removal of Ovaries Affected with Granulosa Theca Cell Tumor (GTCT) in 16 Mares
}

\author{
MD. Shafiqul HOQUE ${ }^{1,2 *}$, Refaat Ibrahim DERAR ${ }^{1,3}$, Nobuo TSUNODA ${ }^{4}$, \\ Hiroyuki SENBA $^{5}$, Takeshi OSAWA ${ }^{1}$ and Yoh-Ichi MIYAKE ${ }^{1}$
}

${ }^{1}$ Laboratory of Theriogenology, Department of Veterinary Medicine, Faculty of Agriculture, Iwate University, Morioka 020-8550, ${ }^{2}$ Department of Clinical Veterinary Science, The United Graduate School of Veterinary Sciences, Gifu University, Gifu 501-1193, ${ }^{3}$ Department of Theriogenology, Faculty of Veterinary Medicine, Assiut University, Assiut, Egypt, ${ }^{4}$ Shadai Stallion Station, Hayakita 059-1432, ${ }^{5}$ NOSAI Hidaka, Clinic Center, Mitsuishi 059-3105, Japan

To clarify the clinical findings in mares with granulosa theca cell tumor (GTCT) and to determine reproductive activity after surgery, 16 mares with GTCT were studied. The GTCTs were found in $10.4 \pm 0.9$ year olds. The clinical signs manifested by the affected animals varied, and the mares showed abnormal behavior, that is, anestrus $(n=5)$, continuous estrus $(n=8)$ and stallion-like behavior $(n=3)$, but most of the affected mares $(11 / 16)$ were sterile for long periods (1-4 years), and in four animals GTCTs were detected at the post-partum period. In 11 of the 16 animals, the ovary containing tumor was enlarged on the right side, whereas the contralateral ovary was atrophied in all the 16 animals. Mares in which the affected ovary was surgically removed in the non-breeding season $(n=8)$ had estrus 2.6 months earlier and became pregnant 2.9 months earlier than those operated on $(n=8)$ in the breeding season, by resuming the reproductive function in the remaining ovary. All three mares that died from hemorrhage after the surgery were operated on in the breeding season. From these results we confirmed that GTCT is related to sterility for long periods in mares and that surgical removal of the affected ovary is effective in restoring reproductive function. And it is also suggested that the affected ovary should be removed in the non-breeding season.

Key words: clinical findings, granulosa theca cell tumor, mare, ovary, ultrasound
J. Equine Sci.

Vol. 13, No. 3

pp. 75-81, 2002
Granulosa theca cell tumors (GTCT) are the most common ovarian neoplasms in the mare [11, 15, 26]. Usually they are benign, unilateral and composed primarily of neoplastic granulosa cells and abnormal theca cells $[10,15]$. Suppression of pituitary gonadotropin output results in atrophy of the contralateral ovary [7], which is considered an important criterion for the diagnosis of GTCT [3, 12, 16, 26-28].

Because of these ovarian abnormalities, the affected mares become sterile for a long time although having abnormal sexual behavior [4, 6, 15], and surgical removal of the affected ovary is effective in restoring

This article was accepted July 26, 2002

*Corresponding author. e-mail: g9901018@iwate-u.ac.jp estrus. Therefore, it is important to diagnose GTCT as soon as possible to improve reproductive performance in mares. GTCTs have been diagnosed by the ultrasonographic patterns [7, 28], and use of ultrasonography as an aid to the diagnosis of GTCT in the mare has been suggested $[9,20]$. GTCT have been described as having a characteristic honeycomb-like appearance with distinct multilocular cysts on ultrasonography $[8,11,15,22,26,27]$. It is important to study the common clinical findings of GTCT, because most papers about GTCT are limited to case reports.

This prospective study utilized a multidisciplinary approach, a) to describe the common clinical signs and diagnostic features associated with GTCT, and b) to gather information regarding reproductive activity after surgery. 


\section{Materials and Methods}

A total of 15 Thoroughbred and one heavy breed with GTCT, which are considered to be representative of the cases seen in different parts of Japan from 1998 to 2001, were investigated in this study. The mares were presented for examination because of reproductive failure or changes in sexual behavior. GTCT was diagnosed by rectal palpation and ultrasonographic image of the ovaries. The affected ovaries were enlarged and the contralateral ovaries were small and atrophic on rectal palpation. After removal of the affected ovaries many large, medium and small follicles in ovaries were found in most of the cases and blood containing follicular fluid was also found in some follicles. On pathological examinations, the sections from the affected ovary were found to be composed of a thick granulosa cell layer with abundant cytoplasm in the theca externa cell layers and in the theca interna cell layers (unpublished data) as shown in another report [26]. At the time we also recorded which ovary was affected ( i.e. left or right).

History information including breed, age, behavior, parity, period of sterility and days from parturition was used in this study. The decision whether the affected ovary should be removed was based on the abnormally large ovary, associated with infertility and behavioral changes. In the majority of animals (15/16) ovariectomy was induced under general anesthesia and maintained with an inhalation anesthesia isoflurane [ Isoflurane; Dainippon Ltd.] via a cuffed endotracheal tube through a flank incision. Total anesthetic time varied between 40 and $100 \mathrm{~min}$. In the other case it was performed under local anesthesia with $70 \mathrm{ml}$ of $2 \%$ lidocaine hydrochloride [Xylocaine; Fujisawa Pharmaceutical Co., Ltd. Osaka] subcutaneously through a standing flank incision. Details of the surgical procedures were similar to those described earlier $[15,21]$ with minor modifications. Of the 16 mares, eight were operated on between October and December, which encompasses the non-breeding season of mares, four were operated on in April and another four were operated in July and September, which encompasses the breeding season of mares [9].

The excised ovaries $(n=16)$ were measured and weighed, and another 20 ovaries from normal mares were examined as controls and compared with the GTCT ovaries. After the removal of the affected ovary, each mare was checked for the periods from surgery to estrous and to pregnancy.
Most of the data are presented as means \pm standard error of the means (SEM). Significance of difference was compared by Student's unpaired $t$-test. All differences in values of $p<0.05$ were considered to be significant.

\section{Results}

The data on breed, age, estrous behavior, parity, period of sterility and days from parturition for each animal are shown in Table 1 . The average age $( \pm$ SEM) of the mares affected with GTCT was $10.4( \pm 0.9)$ years. Seven of the 16 cases were over 13 years old. All the GTCT mares had abnormal sexual behavior. Of the 16 cases $5(31.3 \%)$ affected mares were in the anestrus condition, $8(50.0 \%)$ in continuous estrus and 3 (18.8\%) showed signs of stallion-like behavior. Six primiparous and eight multiparous mares had a parity of $3.2 \pm 0.8$ (mean \pm SEM) and the other 2 animals were maiden. Most of the 16 mares were sterile for more than one year, whereas four were at 10 to 180 days after parturition when they were found to have GTCT.

The surgical procedures and ovarian descriptions are summarized in Table 2. The incidence of GTCT in the right ovary $(11 / 16,68.8 \%)$ is higher than that in the left ovary $(5 / 16,31.2 \%)$. There were a number of follicles of various sizes containing blood follicular fluid (Fig. 1) in GTCT affected ovaries. The affected ovaries were spherical or lobular in appearance. In all cases the normal ovarian architecture was destroyed, the ovulation fossa was undetectable, and the tumor masses were multicystic on the cut surface (Fig. 2).

The 13 mares showed signs of estrus and became pregnant at $6.4 \pm 0.4$ months and $9.7 \pm 1.5$ months after surgery, respectively. Eight mares that were operated on in the breeding season (April to September) returned to the normal estrous cycle at $8.0 \pm 0.6$ months $(n=5)$ and became pregnant at $12.0 \pm 2.3$ months $(n=4)$ after surgery. On the other hand, the other eight mares operated on in the non-breeding season returned to the normal estrous cycle at $5.4 \pm 0.2$ months $(\mathrm{n}=8)$ and became pregnant at $9.1 \pm 1.8$ months $(\mathrm{n}=8)$ after surgery. The time from surgery to the return of the regular estrous cycle changed significantly $(\mathrm{p}<0.05)$ but the time from surgery to pregnancy in the animals operated on in the breeding and the non-breeding season was not significantly different $(p>0.05)$.

The size and weight of the GTCT affected ovaries compared with those of normal ovaries are shown in Table 3. The weight of the neoplastic ovaries ranged 
Table 1. Summary of the GTCT affected ovary

\begin{tabular}{rlrlccc}
\hline Cases & Breed & $\begin{array}{c}\text { Age } \\
\text { (Yrs) }\end{array}$ & Behavior** & Parity & $\begin{array}{c}\text { Period of } \\
\text { sterility (Yrs) }\end{array}$ & $\begin{array}{c}\text { Days from } \\
\text { parturition }\end{array}$ \\
\hline 1 & Thoroughbred & 13 & Continuous estrus & 4 & 3 & $*$ \\
2 & Thoroughbred & 7 & Anestrus & 1 & 0 & 10 \\
3 & Thoroughbred & 8 & Anestrus & 3 & 0 & 180 \\
4 & Thoroughbred & 6 & Continuous estrus & 1 & 0 & 90 \\
5 & Thoroughbred & 5 & Anestrus & 1 & 0 & 49 \\
6 & Thoroughbred & 13 & Anestrus & 1 & 2 & $*$ \\
7 & Thoroughbred & 10 & Continuous estrus & 2 & 3 & $*$ \\
8 & Thoroughbred & 15 & Stallion like behavior & 2 & 4 & $*$ \\
9 & Heavy breed & 5 & Anestrus & 0 & 0 & $*$ \\
10 & Thoroughbred & 13 & Continuous estrus & 1 & 2 & $*$ \\
11 & Thoroughbred & 14 & Stallion like behavior & 8 & 2 & $*$ \\
12 & Thoroughbred & 8 & Continuous estrus & 0 & 0 & $*$ \\
13 & Thoroughbred & 15 & Continuous estrus & 6 & 2 & $*$ \\
14 & Thoroughbred & 16 & Stallion like behavior & 10 & 1 & $*$ \\
15 & Thoroughbred & 10 & Continuous estrus & 4 & 1 & $*$ \\
16 & Thoroughbred & 8 & Continuous estrus & 1 & 1 & $*$ \\
\hline
\end{tabular}

All cases were diagnosed as GTCT in the breeding season. *: maiden in cases 9 and 12, or sterile for more than 1 year (1-4 years). **: Anestrus: 5 cases; Continous estrus: 8 cases; Stallion-like behavior: 3 cases. ***: mean \pm SEM in 14 multiparous mares.

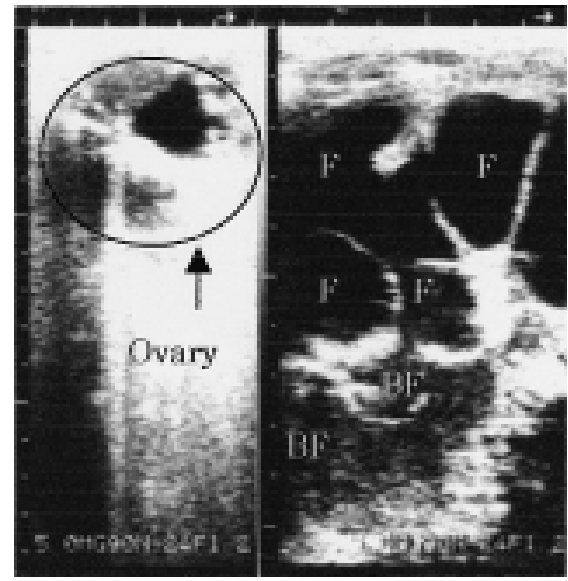

Fig. 1. Ultrasonographic image of the contralateral ovary (Left) and the GTCT affected ovary (Right) from case No. 9. Note the enlarged ovary with a multilocular cyst $(\mathrm{F})$ and some bloody follicular fluid (BF) in the GTCT affected ovary and the atrophic and inactive contralateral ovary.

from $80 \mathrm{~g}$ to $2,000 \mathrm{~g}$, and the average weight was approximately 6 times heavier than that of normal ovaries. The size and weight of the affected ovary

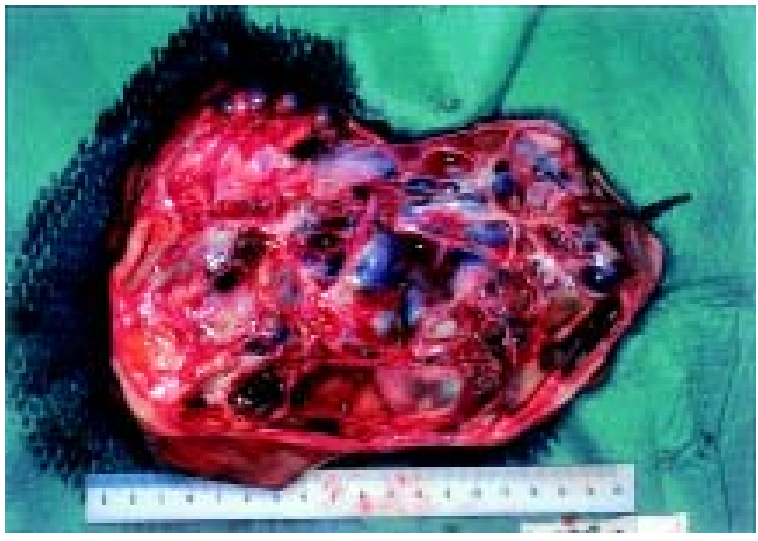

Fig. 2. Cut surface of the GTCT ovary from case No. 2. The multilocular cyst had a characteristic honeycomb appearance on ultrasonographic examination.

associated with ovariectomy performed in the breeding and non-breeding season were $(11.1 \pm 1.4 \mathrm{~cm}$ in length, $9.5 \pm 1.0 \mathrm{~cm}$ in depth, $7.3 \pm 0.9 \mathrm{~cm}$ in width and $12.1 \pm$ $1.9 \mathrm{~cm}$ in length, $9.8 \pm 1.5 \mathrm{~cm}$ in depth, $7.7 \pm 0.9 \mathrm{~cm}$ in width) and (570.8 $\pm 167.2 \mathrm{~g}$ and $753.4 \pm 269.3 \mathrm{~g})$, respectively. The weight of the affected ovaries that were operated on in the non-breeding season was not significantly different $(p>0.05)$ from those in the breeding season. 
Table 2. Clinical findings in mares with GTCT

\begin{tabular}{|c|c|c|c|c|c|c|c|}
\hline \multirow[t]{2}{*}{ Case } & \multirow{2}{*}{\multicolumn{2}{|c|}{$\begin{array}{l}\text { affected } \\
\text { ovary }\end{array}$}} & \multirow[t]{2}{*}{ surgery } & \multicolumn{2}{|c|}{ Season of operation } & \multirow{2}{*}{$\begin{array}{c}\text { Ovarian } \\
\text { Characteristics }\end{array}$} & \multirow{2}{*}{$\begin{array}{c}\text { Follow-up } \\
\text { after surgery }\end{array}$} \\
\hline & & & & breeding & non-breeding & & \\
\hline 1 & & Right & $\mathrm{FI}^{*}$ & April & & $\begin{array}{l}13.0-9.7-6.5 \mathrm{~cm} \\
530 \mathrm{~g}\end{array}$ & Died \\
\hline 2 & & Right & FI & April & & $\begin{array}{l}16.5-14.4-9.5 \mathrm{~cm} \\
1560 \mathrm{~g}\end{array}$ & $\begin{array}{l}\text { Estrus; } 7 \text { months } \\
\text { Pregnant; } 13 \text { months }\end{array}$ \\
\hline 3 & Left & & FI & April & & $\begin{array}{l}13.5-10.0-8.0 \mathrm{~cm} \\
820 \mathrm{~g}\end{array}$ & $\begin{array}{l}\text { Estrus; } 10 \text { months } \\
\text { Pregnant; unknown }\end{array}$ \\
\hline 4 & & Right & FI & July & & $\begin{array}{l}9.0-7.0-6.0 \mathrm{~cm} \\
260 \mathrm{~g}\end{array}$ & $\begin{array}{l}\text { Estrus; } 7 \text { months } \\
\text { Pregnant; } 7 \text { months }\end{array}$ \\
\hline 5 & & Right & FI & April & & $\begin{array}{l}15.0-12.0-12.0 \mathrm{~cm} \\
710 \mathrm{~g}\end{array}$ & Died \\
\hline 6 & Left & & FI & September & & $\begin{array}{l}7.0-10.0-7.5 \mathrm{~cm} \\
410 \mathrm{~g}\end{array}$ & $\begin{array}{l}\text { Estrus; } 9 \text { months } \\
\text { Pregnant; } 9 \text { months }\end{array}$ \\
\hline 7 & & Right & FI & September & & $\begin{array}{l}8.5-7.5-5.5 \mathrm{~cm} \\
196 \mathrm{~g}\end{array}$ & $\begin{array}{l}\text { Estrus; } 7 \text { months } \\
\text { Pregnant; } 18 \text { months }\end{array}$ \\
\hline 8 & Left & & FI & July & & $\begin{array}{l}6.5-5.5-3.5 \mathrm{~cm} \\
80 \mathrm{~g}\end{array}$ & Died \\
\hline 9 & & Right & $\mathrm{SFI}^{* *}$ & & December & $\begin{array}{l}18.0-13.5-11.0 \mathrm{~cm} \\
2000 \mathrm{~g}\end{array}$ & $\begin{array}{l}\text { Estrus; } 5 \text { months } \\
\text { Pregnant; } 8 \text { months }\end{array}$ \\
\hline 10 & & Right & FI & & November & $\begin{array}{l}9.5-9.0-6.5 \mathrm{~cm} \\
380 \mathrm{~g}\end{array}$ & $\begin{array}{l}\text { Estrus; } 5 \text { months } \\
\text { Pregnant; } 5 \text { months }\end{array}$ \\
\hline 11 & Left & & FI & & October & $\begin{array}{l}9.5-7.5-8.0 \mathrm{~cm} \\
400 \mathrm{~g}\end{array}$ & $\begin{array}{l}\text { Estrus; } 6 \text { months } \\
\text { Pregnant; } 17 \text { months }\end{array}$ \\
\hline 12 & Left & & FI & & October & $\begin{array}{l}6.0-5.0-4.2 \mathrm{~cm} \\
150 \mathrm{~g}\end{array}$ & $\begin{array}{l}\text { Estrus; } 6 \text { months } \\
\text { Pregnant; } 7 \text { months }\end{array}$ \\
\hline 13 & & Right & FI & & October & $\begin{array}{l}8.0-7.5-6.5 \mathrm{~cm} \\
214 \mathrm{~g}\end{array}$ & $\begin{array}{l}\text { Estrus; } 6 \text { months } \\
\text { Pregnant; } 7 \text { months }\end{array}$ \\
\hline 14 & & Right & FI & & November & $\begin{array}{l}20.0-17.0-10.0 \mathrm{~cm} \\
1500 \mathrm{~g}\end{array}$ & $\begin{array}{l}\text { Estrus; } 5 \text { months } \\
\text { Pregnant; } 16 \text { months }\end{array}$ \\
\hline 15 & & Right & FI & & December & $\begin{array}{l}13.5-9.0-7.5 \mathrm{~cm} \\
630 \mathrm{~g}\end{array}$ & $\begin{array}{l}\text { Estrus; } 5 \text { months } \\
\text { Pregnant; } 6 \text { months }\end{array}$ \\
\hline 16 & & Right & FI & & November & unknown & $\begin{array}{l}\text { Estrus; } 5 \text { months } \\
\text { Pregnant; } 7 \text { months }\end{array}$ \\
\hline & 5 & 11 & & 8 & 8 & & $\begin{array}{l}\text { Estrus: } 6.4 \pm 0.4 \text { months } \\
\text { Pregnant: } 9.7 \pm 1.5 \text { months }\end{array}$ \\
\hline
\end{tabular}

*FI; Flank incision; **SFI; Standing Flank incision.

\section{Discussion}

Granulosa theca cell tumors (GTCTs) are by far the most common ovarian tumors in the mare and they are macroscopically characterized by their large size and multiloculated cystic architecture [24, 26]. Although a numbr of papers on GTCT in mares have been published, most of them were limited to case reports, and therefore little is known about common and /or specific clinical findings in GTCT mares.

In this study, we observed a large and characteristic honeycomb appearance in the GTCT ovary in all the cases as in other reports $[10,17]$.
In our study, GTCTs were unilateral and benign, and the contralateral ovary was atrophic in all the cases, as described by others [3, 4, 15-18, 21, 23]. It is clear that these findings are considered an important criterion for the diagnosis of GTCT. Piquette et al. [22] have demonstrated that the equine GTCT express the mRNA for inhibin and also secrete inhibin subunits, though they did not measure the peripheral inhibin and FSH levels in their mares with GTCT. It has also been reported that GTCT affected mares secrete abnormal levels of progesterone, testosterone and estradiol [12, 17]. Therefore, in future it will be necessary to study whether or not abnormal hormonal levels may be responsible for the atrophy and inactivity 
Table 3. Size and weight of the GTCT affected ovaries as compared with those of the normal ovaries

\begin{tabular}{|c|c|c|}
\hline Cases & Size $(\mathrm{cm})$ & Weight (g) \\
\hline \multirow[t]{2}{*}{$(n=16)$} & $\begin{array}{c}6.0-20.0 \times \\
5.0-17.0 \times \\
3.5-12.0\end{array}$ & $80-2000$ \\
\hline & $\begin{array}{cc}11.5 \pm 1.4 \\
(\text { length }) & \begin{array}{c}9.6 \pm 0.9 \\
(\text { depth })\end{array} \times 7.5 \pm 0.6 \\
(\text { width })\end{array}$ & $656.0 \pm 150.2$ \\
\hline \multirow[t]{2}{*}{$\begin{array}{l}\text { normal } \\
(\mathrm{n}=20)\end{array}$} & $\underset{(\text { length })(\text { depth })(\text { width })}{5.5 \times 3.5 \times 3.0}$ (minimum $)$ & 35.8-193.4 \\
\hline & $\begin{array}{c}\downarrow \\
9.0 \times 6.0 \times 6.0 \\
(\text { length })(\text { depth })(\text { width }) \quad \text { (maximum) })\end{array}$ & $84.3 \pm 8.0$ \\
\hline
\end{tabular}

a) in the case of operation in breeding season $(n=8)$; weight 80-1560 g (570.75 \pm $167.19)$, size $(11.1 \pm 1.4,9.5 \pm 1.0,7.3 \pm 0.9 \mathrm{~cm})$. b) in the case of operation in non-breeding season $(\mathrm{n}=8)$; weight $150-2000 \mathrm{~g}(753.43 \pm 269.30)$, size $(12.1 \pm$ $1.9,9.8 \pm 1.4,7.7 \pm 0.8 \mathrm{~cm})$. The size and weight of the affected ovaries in breeding season are not significantly different $(p>0.1)$ compared with those in nonbreeding season.

observed in the contralateral ovary.

In most of our cases, GTCT was found in sterility for long period, but in some cases it was found soon after parturition. Pierson and Ginther [21] suggest that the tumors develop during pregnancy but do not interfere with gestation or parturition. In the mare the extensive dissemination of GTCT suggests that it was present during gestation, and that parturition was normal without surgical removal of the affected ovary [13]. The endocrine changes during pregnancy are peculiar to the mare among domestic animal species because of the development of the temporary hormone producing structure, the endometrial cups, from which equine chorionic gonadotropin (eCG) is secreted. In man, human chorionic gonadotropin (hCG) is a marker for ovarian tumor [2]. An increase in hCG occurs in breast, gastro-intestinal tract, lung, melanoma and ovarian cancer. hCG is also increased in some noncancerous conditions such as normal pregnancy, cirrhosis, duodenal ulcer and inflammatory bowel disease. Although eCG is functionally different from hCG and GTCTs are pathologically different from human ovarian cancer, it seems that the increase in eCG in mares may lead to GTCT during pregnancy.

In the present study GTCT affected mares showed signs of anestrus $(5 / 16,31.3 \%)$, continuous estrus (8/ $16,50.0 \%)$ and stallion-like behavior $(3 / 16,18.8 \%)$. This result is different from the previous report [4] in which GTCT affected mares had anestrus (5/14, $35.7 \%)$, continuous estrus $(1 / 14,7.1 \%)$ and stallion like behavior $(8 / 14,57.1 \%)$. Our results are also different from those obtained by others [17] in which affected mares had anestrus $(20 / 63,32 \%)$, continuous estrus $(14 / 63,22 \%)$ and stallion-like behavior (29/63, $46 \%$ ). Behavioral changes may be associated with abnormal hormonal production by the tumor $[14,17]$. In cattle [1] the tumor cells presumably secrete estrogen in the early stages of development of GTCT, and this may cause continuous estrus in the affected animals. Most of the tumor tissue then undergoes luteinization that may lead to an anestrus condition, and may result in virlism in long standing cases [1]. If the estrous behavior in GTCT mares changes with time in the same manner as in GTCT cows, the tumor may have been at a relatively early or mid stage of development of the condition when many of our cases were diagnosed as GTCT.

The incidence of GTCT in the right ovary $(64.7 \%)$ was higher than that in the left ovary $(35.3 \%)$ in this study but the number of GTCT cases that affected the right ovary is about the same as the number that affected the left ovary as reported previously in various different breeds including the Thoroughbred [4-7, 10, 11, 19, 22, 26, 28]. Therefore, the incidence of GTCT is probably not related to the side on which the ovary is located.

Surgical removal of the affected ovary in our cases was performed both in the breeding and in the nonbreeding season. The period between the operation and the resumption of the normal estrous cycle when 
the surgery was performed in the non-breeding season was shorter than that in the breeding season. Mares that are operated on late in the breeding season may not return to cyclic ovarian activity until the next spring [25]. In the present study, four mares were operated on April because the veterinarian expected that the operated mare would have a normal estrous cycle in the same breeding season. Nevertheless, no mare operated on in April or at other times in breeding season returned to the normal estrous cycle in the same breeding season except one (case No.2). In addition, the operation in the breeding season seemed to have a higher degree of risk than that in the non-breeding season because in the present study all of the three mares that died from hemorrhage after surgery were operated on in the breeding season. Presumably the ovarian artery and vein become larger in the breeding season because of higher levels of hormonal activity than in the non-breeding season. Therefore, it may be more complicated to properly ligate ovarian blood vessels in the breeding season. Post surgical complications occurred in most of the mares and some mares died after surgery [17].

The size and weight of the affected ovaries that were operated on in the non-breeding season were not significantly different from those in the breeding season.

GTCT is considered to produce abnormal levels of different kinds of hormones [26] and this might be related to the clinical signs and the differentiation of ovarian tumors. Hormonal profiles for the 16 mares in this study and their relationships to the clinical signs manifested by each animal will be the subject of a future report to confirm the final diagnosis and obtain a more precise grasp of the clinical findings.

In conclusion, although the majority of the mares with GTCT were sterile for a long time, some had the tumor in the postpartum period. And it is clear that surgical removal of the affected ovary is effective in restoring reproductive function in the remnant contralateral atrophic ovary. Also it is recommendable that the GTCT should be removed in the non-breeding season because the operation is more effective in the non-breeding season than that in the breeding season.

\section{References}

1. Arthur, G.H., Noakes, D.E., Pearson, H., and Parkinson, T.J. 1996. Infertility in the cow. p. 355.
In: Veterinary Reproduction and Obstetrics, 7th ed. (Arthur, G.H., Noakes, D.E., and Pearson, H. eds.), W.B. Saunders, Philadelphia.

2. Bagshawe, K.D. 1992. Choriocarcinoma, a model for tumor markers. Acta Oncol. 31: 99-106.

3. Baker, C.B. and Kenney, R.M. 1980. Systematic approach to the diagnosis of the infertile or sub fertile mare. pp. 721-736. In: Current Therapy in Theriogenology, 2nd ed. (Morrow, D.A. ed.), W.B. Saunders, Philadelphia.

4. Bosu, W.T.K., Van Camp, S.C., Miller, R.B., and Owen, R.R. 1982. Ovarian disorders: Clinical and morphologic observations in 30 mares. Can. Vet. J. 23: $6-14$.

5. Cordes, D.O. 1969. Equine Granulosa Tumors. Vet. Rec. 85: 186-188.

6. Daels, P.E. and Hughes, J.P. 1993. The abnormal estrus cycle. pp. 144-160. In: Equine Reproduction, 5th ed. (McKinnen, A.O., and Voss, J.L. eds.) Lea and Febiger, Philadelphia.

7. Gift, L.J., Gaughan, E.M., and Schoning, P. 1992. Metastatic granulosa cell tumor in a mare. J. Am. Vet. Med. Assoc. 200: 1525-1526.

8. Ginther, O.J. 1988. Ultrasonic imaging of ovarian follicles and corpora lutea. Vet. Clin. North Am. Equine Pract. 4: 197-213.

9. Ginther, O.J. 1992. Reproductive seasonality. pp. 105-106. In: Reproductive biology of the mare. 2nd ed. (Ginther, O.J. ed.), Madison, Wisconsin.

10. Hinrichs, K., Elaine, D., Watson, E.D., and Kenney, R.M. 1990. Granulosa cell tumor in a mare with a functional contra lateral ovary. J. Am. Vet. Med. Assoc. 197: 1037-1038.

11. Hinrichs, K. and Hunt, P.R. 1990. Ultrasound as an aid to diagnosis of granulose cell tumor in the mare. Equine Vet. J. 22: 99-103.

12. Hughes, J.P., Kennedy, P.C., and Stabenfeldt, G.H. 1980. Pathology of the ovary and ovarian disorders in the mare. 9th Int. Cong. Anim. Reprod. Artif. Insem. 203-222.

13. Jones, T.C. and Hunt, R.D. 1983. The Genital System. pp. 1516-1517. In: Veterinary Pathology, 5 th ed. (Jones, T.C., and Hunt, R.D. eds.), Lea and Febiger, Philadelphia.

14. Jubb, K.V.F., Kennedy, P.C., and Palmer, N. 1980. The Female Genital System. p. 320. In: Pathology of Domestic Animals, 3rd ed. (Jubb, K.V.F., Kennedy, P.C., and Palmer, N. eds.), Academic Press, Florida.

15. Liu, I.K.M. 1987. Ovarian abnormalities. pp. 500503. In: Current Therapy in Equine Medicine, 2nd ed. (Robinson, N.E. ed.), W.B. Saunders, 
Philadelphia.

16. Mckinnen, A.O., Voss, J.L., Squires, E.L., and Carnevale, E.M. 1993. Diagnostic Ultrasonography. pp. 266-302. In: Equine Reproduction, 2nd ed. (Mckinnen, A.O., and Voss, J.L. ed.), Lea and Febiger, Philadelphia.

17. Meghar, D.M., Wheat, J.D., Hughes, J.P., Stabenfeldt, G.H., and Harris, B.A. 1977. Granulosa cell tumor in mares a review of 78 cases. Proc. Am. Equine Pract. 133-143.

18. Moulton, J.E. 1990. Genital systems. pp. 504-507. In: Tumors in domestic animals, 3rd ed. (Nielsen S.W., and Kenney, P.C. eds), University of California Press, Berkeley.

19. Panciera, R.J., Slusher, S.A., and Hayes, K.E.N. 1991. Ovarian teratoma and Granulosa cell tumor in two mares. Cornell Vet. 81: 43-50.

20. Perino, L.J. and Didier, P.J. 1985. Equine granulosa cell tumors. Equine Practice 7: 14-17.

21. Pierson, R.A. and Ginther, O.J. 1987. Follicular population dynamics during the estrus cycle of the mare. Anim. Reprod. Sci. 14: 219-231.

22. Piquette, G.N., Kenney, R.M., Sertich, P.A., Yamoto, M., and Hsueh, J.W. 1990. Equine granulosa-theca cell tumor express inhibin-A- and $\beta$ A subunit messenger ribonucleic acids and proteins. Biol. Reprod. 43: 1050-1057.

23. Pugh, D.G. and Bowen, J.M. 1985. Equine ovarian tumors. Comp. Cont. Educ. Pract. Vet. 7: S710-S715.

24. Scott, E.A. and Kunze, D.J. 1977. Ovariectomy in the mare: presurgical, surgical and post surgical considerations. Piquette, G.N., Kenney, R.M., Sertich, P.A., Yamoto, M., and Hsueh, J.W. 1990. Equine granulosa-theca cell tumor express inhibin-A- and $\beta$ A subunit messenger ribonucleic acids and proteins. Biol. Reprod. 43: 1050-1057.

25. Stabenfeldt, G.H., Hughes, J.P., Kennedy, P.C., Meghar, D.M. and Neely, D.P. 1979. Clinical findings, pathological changes and endocrinological secretory patterns in mares with ovarian tumors. J. Reprod. Fertil. Suppl. 27: 277-285.

26. Stickle, R.L., Erb, R.E., Fessler, J.F., and Runnels, L.J. 1975. Equine granulosa cell tumors. J. Am. Vet. Med. Ass. 167: 148-151.

27. Watson, E.D. 1999. Granulosa cell tumors in the mare:- a review of 9 cases. Equine Vet. Educ. 11: 136142.

28. White, R.A.S. and Allen, W.R. 1985. Use of ultrasound echography for the differential diagnosis of granulosa cell tumor in a mare. Equine Vet. J. 17: 401-402. 